\title{
Effects of nicotine on uterine blood flow and intrauterine oxygen tension in the rat*
}

\author{
R. E. Hammer, H. Goldman and J. A. Mitchell \\ Departments of Anatomy and Pharmacology, Wayne State University, School of Medicine, \\ Detroit, Michigan 48201, U.S.A.
}

\begin{abstract}
Summary. Subcutaneous injection of nicotine $(0.5$ or $5 \mathrm{mg} / \mathrm{kg}$ body wt) resulted in a marked and prolonged reduction in uterine blood flow and intrauterine oxygen tension in pseudopregnant rats. By $10 \mathrm{~min}$ after nicotine administration $(5 \mathrm{mg} / \mathrm{kg})$ uterine perfusion was reduced by $40 \%$, remained suppressed for $90 \mathrm{~min}$ and returned to the pre-treatment level by $120 \mathrm{~min}$. Rats receiving the $0.5 \mathrm{mg}$ nicotine $/ \mathrm{kg}$ also showed a marked reduction in uterine blood flow, although the response was slower in onset and longer in duration. Nicotine $(5 \mathrm{mg} / \mathrm{kg})$ also resulted in a sustained decrease in intrauterine oxygen tension from a control value of $48.9 \pm 3.6$ to $22.2 \pm 2.6 \mathrm{mmHg}$ at $45-60 \mathrm{~min}$ and $21.7 \pm 1.5 \mathrm{mmHg}$ at $60-90 \mathrm{~min}$. The frequency and amplitude of fluctuations in intrauterine oxygen tension were still reduced by $90 \mathrm{~min}$ after treatment.
\end{abstract}

\section{Introduction}

Cigarette smoking during pregnancy increases the incidence of abortion, developmental anomalies and small-for-date infants (Hollinshead, 1979). Similarly, in rats, protracted administration of nicotine, an alkaloid of cigarette smoke, causes increased fetal wastage (Hudson \& Timiras, 1972) and small-for-date young (Becker, Little \& King, 1968). In addition, injection of the alkaloid during the initial 5 days of pregnancy delays blastocyst implantation (Card \& Mitchell, 1979) and retards embryo growth (Hammer \& Mitchell, 1979; Yoshinaga, Rice, Krenn \& Pilot, 1979). The nicotine-induced suppression of embryo growth is associated with ovarian steroid hormone imbalance (Yoshinaga et al., 1979) and a marked and protracted reduction in reproductive tract blood flow (Hammer, Mitchell \& Goldman, 1981). Since normal conceptus development requires optimal levels of oxygen, the impaired embryo growth observed in nicotine-treated animals may result, in part, from decreased oxygen availability within the reproductive tract. The following study was undertaken to determine whether the nicotineinduced reduction in uterine blood flow concomitantly decreases the concentration of oxygen within the uterine lumen.

\section{Materials and Methods}

\section{Animals}

Mature virgin female rats of the Sprague-Dawley strain (Camm Research Institute), 200-350 g body weight, were maintained under environmental conditions controlled with respect to room temperature $\left(20-25^{\circ} \mathrm{C}\right)$, humidity $(40-60 \%)$ and photoperiod $(14 \mathrm{~h}$ light

* Reprint requests to Dr J. A. Mitchell. 
$(06: 00-20: 00 \mathrm{~h}) / 24 \mathrm{~h})$. Animals were caged in pairs with free access to Purina Lab Chow and water. Vaginal smears were examined daily to determine the stage of the oestrous cycle. Each rat had exhibited at least 2 consecutive 4- or 5-day cycles before use. The effects of nicotine on uterine blood flow and intraluminal uterine oxygen tension were investigated in pseudopregnant rather than pregnant rats in order to avoid the difficulties of measuring intrauterine $\mathrm{PO}_{2}$ in gravid uteri. Pseudopregnancy was induced by stimulating the cervix with a glass rod on the afternoon of pro-oestrus and the morning of oestrus. Day 0 of pseudopregnancy was defined as the last day of vaginal cornification (oestrus) before the onset of the luteal phase. Only rats exhibiting 4 consecutive days of leucocytic smears were used.

\section{Nicotine treatment}

Between 13:00 and 15:00 $\mathrm{h}$ on the afternoon of Day 4 of pseudopregnancy, randomly selected animals were injected subcutaneously (s.c.) with 5 or $0.5 \mathrm{mg}$ nicotine/kg body weight or with $0.1 \mathrm{ml}$ saline $(9 \mathrm{~g} \mathrm{NaCl} / \mathrm{l})$ (controls). Doses were prepared by dilution of a $98 \%$ nicotine solution (Eastman Kodak Co.) with saline within $\mathbf{3 0}$ min of the time of injection.

\section{Measurement of uterine blood flow and cardiac output}

Nutritive blood flow, measured by a modification of the method of Sapirstein (1958), was determined in pseudopregnant rats on the afternoon of Day 4 at 10,20, 45, 90 and 120 min after a s.c. injection of saline or nicotine. Since cardiac output and organ blood flows in rats receiving saline did not change with time, control measurements were pooled. Animals were anaesthetized with an intraperitoneal injection of pentobarbitone sodium $(40 \mathrm{mg} / \mathrm{kg})$ approximately $15 \mathrm{~min}$ before blood flow measurement. Heparin-containing polyethylene catheters were placed in the femoral vein and contralateral femoral artery. At the time of measurement, approximately $7 \mu \mathrm{Ci}{ }^{86} \mathrm{Rb}$ indicator of $50 \mu \mathrm{l}$ saline were injected via the venous catheter. Simultaneous collection of blood from the arterial catheter permitted the determination of cardiac output. At $20 \mathrm{sec}$ after label infusion, animals were killed by intravenous injection of $0.2 \mathrm{ml}$ saturated potassium chloride solution. Uteri, adrenals, anterior and posterior pituitary glands were removed, rapidly cleaned of connective tissue, and weighed. The radioactive content of the whole organs was measured in a Packard auto-gamma counter. Ovarian blood flow was not assessed because the $\mathbf{R b}^{86}$ fractionation technique underestimates the perfusion rate of the ovary due to a low ovarian extraction of the radionuclide (Janson \& Albrecht, 1975). Nutritive blood flow, defined as the exchangeable portion of total blood flow, was expressed as $\mathrm{ml} / \mathrm{min} / \mathrm{g}$ tissue.

\section{Measurement of intrauterine oxygen tension}

Intrauterine oxygen tension $\left(\mathrm{PO}_{2}\right)$ was measured in vivo with an oxygen microelectrode as previously described (Garris \& Mitchell, 1979). Between 13:00 and 16:00 h on Day 4 of pseudopregnancy, animals were anaesthetized with an intraperitoneal injection of pentobarbitone sodium $(40 \mathrm{mg} / \mathrm{kg})$ and the tubal end of a uterine horn was exposed by a flank incision. The calibrated electrode was inserted into the uterine lumen through a small incision at the uterotubal junction, and intrauterine $\mathrm{PO}_{2}$ was recorded. Oxygen tension was measured for $15-30 \mathrm{~min}$ before and at 45 or $60 \mathrm{~min}$ after a s.c. injection of nicotine $(5 \mathrm{mg} / \mathrm{kg})$. Normal body temperature, monitored with a rectal thermometer, was maintained with heat from an incandescent light. At the end of the recording period, electrode calibration was confirmed. Only recordings in which the deviation in calibration was $\leq 3 \mathrm{mmHg}$ were used. Mean oxygen tension and the amplitude and frequency of changes in $\mathrm{PO}_{2}$ were computed as previously described (Mitchell \& Yochim, 1968b). 
Data analysis

Sample means from control and experimental groups were compared for significance of differences by two-tailed Student's $t$ test.

\section{Results}

Effect of nicotine on blood flow and cardiac output

As shown in Table 1, the higher dose of nicotine evoked a marked reduction in uterine blood flow which was rapid in onset and protracted in duration. Uterine perfusion was reduced by 10 min after injection and remained suppressed $(40 \%)$ until returning to the control level by 120 min. In contrast, anterior and posterior pituitary gland blood flow remained unchanged, as did adrenal perfusion, except at $120 \mathrm{~min}$. Cardiac output in nicotine-treated rats differed from that of controls only at 45 and $90 \mathrm{~min}$.

Table 1. Effects of a single injection of nicotine on cardiac output and blood flow through various organs

Time after injection (min)

\begin{tabular}{cccccc}
\hline $\begin{array}{c}0 \\
\text { (control) }\end{array}$ & 10 & 20 & 45 & 90 & 120 \\
\multicolumn{7}{c}{} & 5.0 mg nicotine $/ k g$ & 5 & & 9 \\
$414 \pm 14$ & $388 \pm 29$ & $402 \pm 46$ & $313 \pm 29^{* *}$ & $317 \pm 21^{* *}$ & $364 \pm 24$
\end{tabular}

\begin{tabular}{|c|c|c|c|c|c|c|}
\hline $\begin{array}{l}\text { No. of rats } \\
\text { Cardiac } \\
\text { output } \\
(\mathrm{ml} / \mathrm{min} / \mathrm{kg})\end{array}$ & $\begin{array}{c}5 \\
414 \pm 14\end{array}$ & $\begin{array}{rl} & 5 \\
388 & 29\end{array}$ & $\begin{array}{c}\quad 6 \\
402 \pm 46\end{array}$ & $\begin{array}{c}5 \\
313 \pm 29^{* *}\end{array}$ & $\begin{array}{c}7 \\
317 \pm 21^{* *}\end{array}$ & $\begin{array}{c}9 \\
364 \pm 24\end{array}$ \\
\hline \multicolumn{7}{|l|}{$\begin{array}{l}\text { Blood flow } \\
(\mathrm{ml} / \mathrm{min} / \mathrm{g})\end{array}$} \\
\hline Uterus & $0.47 \pm 0.05$ & $0.28 \pm 0.08^{* * *}$ & $0.22 \pm 0.04^{* * *}$ & $0.20 \pm 0.05^{* * *}$ & $0.25 \pm 0.09^{* * *}$ & $0.39 \pm 0.05$ \\
\hline $\begin{array}{l}\text { Anterior } \\
\text { pituitary }\end{array}$ & $0.54 \pm 0.07$ & $0.56 \pm 0.08$ & $0.56 \pm 0.10$ & $0.48 \pm 0.03$ & $0.40 \pm 0.02$ & $0.46 \pm 0.01$ \\
\hline $\begin{array}{l}\text { Posterior } \\
\text { pituitary }\end{array}$ & $5.53 \pm 0.53$ & $5 \cdot 50 \pm 0 \cdot 31$ & $6.00 \pm 0.59$ & $4 \cdot 74 \pm 0 \cdot 50$ & $4.53 \pm 0.55$ & $5.62 \pm 0.24$ \\
\hline Adrenal & $3.64 \pm 0.21$ & $3.48 \pm 0.39$ & $3.76 \pm 0.2 \mathrm{~J}$ & $3.26 \pm 0.06$ & $3.58 \pm 0.76$ & $4.74 \pm 0.13^{* *}$ \\
\hline \multicolumn{7}{|c|}{$0.5 \mathrm{mg}$ nicotine $/ \mathrm{kg}$} \\
\hline $\begin{array}{l}\text { No. of rats } \\
\text { Cardiac } \\
\text { output } \\
(\mathrm{ml} / \mathrm{min} / \mathrm{kg})\end{array}$ & $\begin{array}{c}5 \\
414 \pm 14\end{array}$ & $\begin{array}{c}5 \\
468 \pm 11\end{array}$ & $\begin{array}{c}6 \\
431 \pm 42\end{array}$ & $\begin{array}{c}5 \\
446 \pm 33\end{array}$ & $\begin{array}{c}5 \\
469 \pm 14\end{array}$ & $\begin{array}{c}6 \\
404 \pm 45\end{array}$ \\
\hline \multicolumn{7}{|l|}{$\begin{array}{l}\text { Blood flow } \\
(\mathrm{ml} / \mathrm{min} / \mathrm{g})\end{array}$} \\
\hline Uterus & $0.47 \pm 0.05$ & $0.40 \pm 0.11$ & $0.26 \pm 0.01^{* *}$ & $0.29 \pm 0.05^{*}$ & $0.32 \pm 0.05^{*}$ & $0.27 \pm 0.02^{* *}$ \\
\hline $\begin{array}{l}\text { Anterior } \\
\text { pituitary }\end{array}$ & $0.54 \pm 0.07$ & $0.58 \pm 0.08$ & $0.69 \pm 0.09$ & $0.68 \pm 0.11$ & $0.52 \pm 0.06$ & $0.72 \pm 0.16^{* *}$ \\
\hline $\begin{array}{l}\text { Posterior } \\
\text { pituitary }\end{array}$ & $5.53 \pm 0.53$ & $5.87 \pm 0.48$ & $6.24 \pm 0.75$ & $6.29 \pm 0.79$ & $5 \cdot 16 \pm 0.30$ & $6.20 \pm 0.46$ \\
\hline Adrenal & $3.64 \pm 0.21$ & $4.43 \pm 0.34$ & $4.57 \pm 0.28$ & $3.71 \pm 0.76$ & $4.54 \pm 0.33$ & $4.74 \pm 0.38^{* *}$ \\
\hline
\end{tabular}

Values are mean \pm s.e.m.

Values significantly different from that at $0 \mathrm{~min}:{ }^{*} P<0.05 ;{ }^{* *} P<0.01{ }^{* * *} P<0.005$.

Administration of the lower dose of nicotine markedly reduced uterine blood flow without affecting cardiac output (Table 1). In addition, the uterine response was slower in onset and longer in duration than that induced by the $5 \mathrm{mg}$ dose; uterine blood flow was still suppressed at $120 \mathrm{~min}$. There were no changes in blood flow in the other organs tested except at $120 \mathrm{~min}$ when there was an increased flow in the anterior pituitary and adrenal glands. 


\section{Effects of nicotine on intrauterine oxygen tension}

Nicotine administration resulted in a prompt and sustained decrease in intrauterine $\mathrm{PO}_{2}$ (Table 2). Nicotine also caused marked differences in frequency and amplitude of the rhythmic moment-to-moment changes in $\mathrm{Po}_{2}$ (Table 2).

Table 2. Effects of a single injection of nicotine $(5 \mathrm{mg} / \mathrm{kg})$ on mean \pm s.e.m. intrauterine oxygen tension and frequency and amplitude of change in $\mathrm{PO}_{2}$

\begin{tabular}{ccccc}
\hline $\begin{array}{c}\text { Time } \\
(\mathrm{min})\end{array}$ & $\begin{array}{c}\text { No. } \\
\text { of rats }\end{array}$ & $\begin{array}{c}\mathrm{PO}_{2} \\
(\mathrm{mmHg})\end{array}$ & $\begin{array}{c}\text { Frequency } \\
\text { (peaks/h) }\end{array}$ & $\begin{array}{c}\text { Amplitude } \\
(\mathrm{mmHg})\end{array}$ \\
\hline 0 & 5 & $48.9 \pm 3.6$ & $45.3 \pm 8.7$ & $16.2 \pm 3.2$ \\
$45-60$ & 5 & $22.2 \pm 2.6^{* *}$ & $27.0 \pm 2.7^{*}$ & $1.1 \pm 0.3^{* *}$ \\
$60-90$ & 5 & $21.7 \pm 1.5^{* *}$ & $33.0 \pm 3.9^{*}$ & $1.5 \pm 0.8^{* *}$ \\
\hline
\end{tabular}

Significantly different from value at $0 \mathrm{~min}:{ }^{*} P<0.01$; ${ }^{* *} P<0.005$.

\section{Discussion}

The results of this study indicate that nicotine, in amounts sufficient to suppress embryonic growth, reduces uterine blood flow and produces a marked and sustained decrease in oxygen tension within the uterine lumen. The time-course of the reduction in intrauterine oxygen availability parallels that of the nicotine-induced decrease in uterine blood flow. The close temporal relationship existing between uterine haemodynamics and oxygen tension within the uterine lumen is consistent with observations demonstrating the importance of uterine vascular state among the diverse determinants of luminal $\mathrm{PO}_{2}$ (Mitchell \& Yochim, 1968a, b). The reduction in intraluminal oxygen tension from 49 to $22 \mathrm{mmHg}$ was sufficient to produce a relatively hypoxic environment within the uterus. In view of the importance of oxidative metabolism in normal embryo development (Brinster, 1972), the intrauterine hypoxia accompanying the reduction of uterine blood flow probably plays a major role in the suppression of embryo growth by the alkaloid.

The importance of oxygen for normal embryo growth has been demonstrated both in vivo and in vitro. Before the blastocyst attaches to the uterine wall, it relies on diffusion to acquire oxygen and other metabolic substrates. As cell division proceeds, the oxidative metabolic needs of the conceptus increase (Brinster, 1973) and are met by an elevation in intrauterine oxygen tension (Yochim \& Mitchell, 1968). Reducing oxygen availability at the time of implantation by administering vasoconstrictive drugs (Crist \& Hulka, 1970; Hammer, 1980; Hammer \& Mitchell, 1980), occluding uterine arteries (Franklin \& Brent, 1964) or exposing pregnant animals to an hypobaric atmosphere (Blackburn \& Clegg, 1979) impairs embryo development and/or terminates pregnancy. Similarly, blastocyst attachment and conceptus growth in vitro require optimal concentrations of oxygen (Glenister, 1963). Furthermore, the rapidity with which transtrophoblast potential changes consequent to decreased oxygen concentration reveals the blastocyst to be keenly sensitive to $\mathrm{PO}_{2}$ (Cross \& Brinster, 1970). It is therefore possible that during early development the conceptus is particularly vulnerable to transient episodes of intrauterine hypoxia resulting from nicotine-induced reduction of uterine blood flow.

Alternatively, the decrease in cell division observed in conceptuses retrieved from the uteri of nicotine-treated rats (Card \& Mitchell, 1979; Hammer \& Mitchell, 1979) may not result primarily from decreased uterine blood flow but rather from ovarian steroid hormone imbalance (Yoshinaga et al., 1979) and/or direct action of the alkaloid on the conceptus (Fabro \& Sieber, 1969). However, experiments in progress indicate that a single injection of nicotine, in addition to reducing reproductive tract blood flow, retards conceptus growth. The effectiveness of a single 
injection rules out alterations in steroid balance as being a primary cause of reduced embryo growth because multiple doses of nicotine are required to alter gonadotrophin and ovarian steroid secretion (Blake, Scaramuzzi, Norman, Kanematsu \& Sawyer, 1972; Yoshinaga et al., 1979), and changes in the uterine environment brought about by ovarian steroids occur relatively slowly (Yochim, 1975).

How nicotine reduces uterine blood flow in rats is unknown, but in ewes it does so indirectly via systemic release of norepinephrine (Resnik, Brink \& Wilkes, 1979). It is likely that the alkaloid alters uterine vasodynamics in the rat in a similar fashion. The uterus of the rat receives adrenergic innervation (Adham \& Schenk, 1969); topical application of epinephrine to the uterus produces vascular constriction and a precipitous decline in intrauterine $\mathrm{Po}_{2}$ (Mitchell \& Yochim, 1968a), and injection of norepinephrine during early pregnancy prevents, presumably via uterine ischaemia, implantation (Crist \& Hulka, 1970). The dramatic effect of the alkaloid on the frequency and amplitude of change in intrauterine oxygen tension indicates altered vascular activity. Such moment-to-moment changes in luminal $\mathrm{PO}_{2}$ result from alternate constriction and dilatation of the uterine arterioles regulating blood flow to the endometrium (Mitchell \& Yochim, 1968a). Thus, the protracted loss of amplitude following nicotine administration indicates sustained vascular constriction and is consistent with the observed reduction in uterine blood flow and luminal $P_{2}$.

The doses of nicotine employed in the present experiments exceed those encountered during cigarette smoking (Armitage et al., 1975; Russell, Wilson, Patel, Feyerabend \& Cole, 1975). However, since one-tenth the dose of nicotine $(0.5 \mathrm{mg} / \mathrm{kg}$ body wt) also reduces uterine blood flow, the alkaloid probably has growth-suppressing effects on conceptus development at lower doses than previously demonstrated (Hammer \& Mitchell, 1979). In spite of differences in dosage, route of administration and species, the results may be relevant to smoking-related changes in human fetal development. Even the small amount of nicotine inhaled during cigarette smoking is sufficient to evoke fetal hypoxia (Manning \& Feyerabend, 1976). Such transitory impairment of fetal well-being presumably arises from nicotine-induced release of catecholamines (Quigley, Sheehan, Wilkes \& Yew, 1979) to which the human uterine vasculature is extremely responsive (Anderson, Still \& Griess, 1977). The results of the present study raise the possibility that, as in the rat, nicotine may reduce the availability of oxygen within the human uterus and influence the conceptus even before it implants.

This research is part of a dissertation submitted by R.E.H. to the Graduate School of Wayne State University in partial fulfilment of the requirements for the degree of $\mathrm{Ph} . \mathrm{D}$. We thank Sharon Murphy for help in measuring blood flow and Dr Bent G. Boving for helpful suggestions and careful review of the manuscript. This work was supported by a grant to J.A.M. from the Council for Tobacco Research Inc., USA (No. 1012).

\section{References}

Adham, N. \& Schenk, E.A. (1969) Autonomic innervation of the rat vagina, cervix and uterus and its cyclic variation. Am.J. Obstet. Gynec. 104, 508-516.

Anderson, S.G., Still, J.G. \& Griess, F.C. (1977) Differential reactivity of the gravid uterine vasculatures: effect of norepinephrine. Am. J. Obstet. Gynec. 129, 293-297.

Armitage, A.K., Dallery, C.T., George, C.F., Houseman, T.H., Lewis, P.J. \& Turner, D.M. (1975) Absorption and metabolism of nicotine from cigarettes. Br. med. J. 4, 313-316.
Becker, R.F., Little, C. \& King, J. (1968) Experimental studies on nicotine absorption in rats during pregnancy. III. Effect of subcutaneous injection of small chronic doses upon mother, fetus and neonate. Am.J. Obstet. Gynec. 100, 957-968.

Blackburn, R.O. \& Clegg, E.J. (1979) The survival and implantation of mouse blastocysts at varying degrees of reduced atmospheric pressure. Teratology 20, 441-446.

Blake, C.A., Scaramuzzi, R.J., Norman, R.L., Kanematsu, S. \& Sawyer, C.H. (1972) Effect of Downloaded from Bioscientifica.com at 04/26/2023 08:54:13AM 
nicotine on the proestrous ovulatory surge of $\mathrm{LH}$ in the rat. Endocrinology 91, 1253-1258.

Brinster, R. (1972) Developing zygote. In Reproductive Biology, pp. 748-775. Eds H. Balin \& S. Glasser. Excerpta Medica, Amsterdam.

Brinster, R.L. (1973) Lactate dehydrogenase isozyme in the pre-implantation rabbit embryo. Biochem. Genet. 9, 229-234.

Card, J.P. \& Mitchell, J.A. (1979) The effects of nicotine on implantation in the rat. Biol. Reprod. 20, 532-539.

Crist, T.Y. \& Hulka, J.F. (1970) Influence of maternal epinephrine on behavior of offspring. Am. J. Obstet. Gynec. 106, 687-691.

Cross, M.H. \& Brinster, R.L. (1970) Influence of ions, inhibitors and anoxia on transtrophoblast potential of the rabbit blastocyst. Expl Cell Res. 62, 303-309.

Fabro, S. \& Sieber, S. (1969) Caffeine and nicotine penetrate the pre-implantation blastocyst. Nature, Lond. 233, 410-411.

Franklin, J.B. \& Brent, R.L. (1964) The effect of uterine vascular clamping on the development of rat embryos three to fourteen days old. J. Morph. 115, 273-290.

Garris, D.R. \& Mitchell, J.A. (1979) Intrauterine oxygen tension during the estrous cycle in the guinea pig: its relation to uterine blood volume and plasma estrogen and progesterone levels. Biol. Reprod. 21, 149-159.

Glenister, T.W. (1963) Observations on mammalian blastocysts implanting in organ culture. In Delayed Implantation, pp. 171-182.Ed. A. Enders. University of Chicago Press.

Hammer, R.E. (1980) Embryotoxic effects of serotonin during early pregnancy in the rat. Anat. Rec. 196, 71-72A.

Hammer, R.E. \& Mitchell, J.A. (1979) Nicotine reduces embryo growth, delays implantation, and retards parturition in rats. Proc. Soc. exp. Biol. Med. 162, 333-336.

Hammer, R.E. \& Mitchell, J.A. (1980) 5-Hydroxytryptamine induced disruption of implantation in the rat: possible modes of action. Biol. Reprod. 22, $29 \mathrm{~A}$.

Hammer, R.E., Mitchell, J.A. \& Goldman, H. (1981) Effects of nicotine on conceptus cell proliferation and oviductal/uterine blood flow in the rat. In Cellular and Molecular Aspects of Implantation, pp. 439-
442. Eds S. Glasser \& D. Bullock. Plenum Press, New York.

Hollinshead, N.H. (1979) The consequences of smoking in pregnancy. Rhode Isl. med.J. 62, 207-212.

Hudson, D.B. \& Timiras, P.S. (1972) Nicotine injection during gestation: impairment of reproduction, fetal viability and development. Biol. Reprod. 7, 247253.

Janson, P.O. Albrecht, I. (1975) Methodological aspects of blood flow measurement in ovaries containing corpora lutea. J. appl. Physiol. 38, 288-293.

Manning, F.A. \& Feyerabend, C. (1976) Cigarette smoking and fetal breathing movements. Br. J. Obstet. Gynaecol. 83, 262-270.

Mitchell, J.A. \& Yochim, J.M. (1968a) Intrauterine oxygen tension during the estrous cycle in the rat: its relation to uterine respiration and vascular activity. Endocrinology 83, 701-705.

Mitchell, J.A. \& Yochim, J.M. (1968b) Measurement of oxygen tension in the rat and its regulation by ovarian steroid hormones. Endocrinology 83, 691700.

Quigley, M.E., Sheehan, K.L., Wilkes, M.M. \& Yew, S.S.C. (1979) Effects of maternal smoking on circulating catecholamine levels and fetal heart rates. Am. J. Obstet. Gynec. 133, 685-690.

Resnik, R., Brink, G.W. \& Wilkes, M. (1979) Catecholamine-mediated reduction in uterine blood flow after nicotine infusion in the pregnant ewe. J. clin. Invest. 63, 1133-1136.

Russell, M.A.H., Wilson, C, Patel, F.A., Feyerabend, C. \& Cole, P.V. (1975) Plasma nicotine levels after smoking cigarettes with high, medium and low nicotine yields. $B r$. med. J. 2, 414-416.

Sapirstein, L.A. (1958) Regional blood flow by fractional distribution of indicators. Am. J. Physiol. 193, 161-168.

Yochim, J.M. (1975) Development of the progestational uterus: metabolic aspects. Biol. Reprod. 12, 106133.

Yochim, J.M. M Mitchell, J.A. (1968) Intrauterine oxygen tension in the rat during progestation: its possible relation to carbohydrate metabolism and the regulation of nidation. Endocrinology 83, 706-713.

Yoshinaga, K., Rice, C., Krenn, J. \& Pilot, R.L. (1979) Effects of nicotine on early pregnancy in the rat. Biol. Reprod. 20, 294-303. 